International Research Journal of Management, IT \& Social Sciences
Available online at https://sloap.org/journals/index.php/irjmis/
Vol. 7 No. 1, January 2019, pages: 31 36
ISSN: 2395-7492
https://doi.org/10.21744/irjmis.v7n1.819

\title{
The Impact of Tourism Development on the Economic, Cultural and Environmental Aspects of Local Communities
}

\section{Article history:}

Received: 09 November 2019

Accepted: 27 December 2019

Published: 09 January 2020

\section{Keywords:}

culture;

economy;

environment;

local community;

tourism development;

\begin{abstract}
The growing development of tourism in Canggu Village encourages researchers to analyze the Impact of Tourism Development on Economic, Cultural and Environmental Aspects of the Local Community of Canggu Village in Badung Regency. The population in this study is the local community of Canggu Village which is divided into 7 banjar adat (community). The sampling method that I used was random sampling where 30 questionnaires were distributed in each banjar adat so that a total of 210 respondents were obtained. The data analysis technique that the researchers used was Path Analysis. The results show that: (1) the variable of tourism development has a significant positive effect on economic variables; (2) the variable of tourism development has a significant positive effect on cultural variables; (3) the variable of tourism development has a significant positive effect on environmental variables.
\end{abstract}

International research journal of management, IT and social sciences (C) 2020. This is an open access article under the CC BY-NC-ND license (https://creativecommons.org/licenses/by-nc-nd/4.0/).

\section{Author correspondence:}

I Gede Surya Pratama,

Faculty of Economics and Business, University of Warmadewa, Denpasar, Indonesia.

Email address: pratama049@gmail.com

\footnotetext{
a University of Warmadewa, Denpasar, Indonesia

${ }^{\mathrm{b}}$ University of Warmadewa, Denpasar, Indonesia
} 


\section{Introduction}

Tourism is an important role in the process of regional development and development in a country. The tourism sector has a large correlation and a variety of potential in supporting productive economic sectors, with the presence of tourism, the community economy is growing such as the so many employments, the development of the business, including the level of welfare (Putri \& Abdillah, 2019; Amerta et al., 2018). In addition to the economic sector, the cultural sector was also influenced by the tourism sector. In many countries which have a wide variety of cultures is a very high attraction for tourists as a reason to make a visit. An interesting and unique culture can make tourists not only visit once to the country but repeatedly in visiting to enjoy the unique culture of a country. Besides Culture. Tourism is also one of the sectors that affect the sustainability of the surrounding environment. Tourism development is closely related to the quality of the environment that must be maintained because in the tourism sector the environment is one of the attractions that has a very high role in influencing visitor satisfaction.

Bali is an island that has a variety of tourist attractions that are already well-known throughout the country. A variety of attractions are presented on the island of Bali such as nature, arts, and culture, culinary, even hospitality of the local community. According to data collected by the Central Statistics Agency of Bali, both domestic and foreign tourists visiting the island of Bali continue to increase from year to year. Data on domestic and foreign visits can be seen in the following table:

Table 1

Quantity of domestic and overseas tourist visits by the central statistics agency of Bali province

\begin{tabular}{lll}
\hline Year & Domestic & Overseas \\
\hline 2014 & 6.394 .307 & 3.766 .638 \\
2015 & 7.147 .100 & 4.001 .835 \\
2016 & 8.643 .680 & 4.927 .937 \\
2017 & 8.735 .633 & 5.697 .739 \\
\hline
\end{tabular}

Sources: Central Statistics Agency of Bali Province, 2019

Based on these data sources it can be said that the island of Bali is still a favorite tourism area for tourists both from within and outside the country. The attractiveness of tourism is spread almost throughout the regions in Bali, one of them is Canggu Village. Canggu Village is a new favorite tourism destination for foreign and domestic tourists located in North Kuta. Canggu village has a beach with big waves that are favored by surfers from various countries. A few years ago Canggu Village was just a paddy field, not many tourists knew about this tourism area. But now it has developed very fast and become one of the beach tourism destinations in Bali.

Canggu Village continues to experience developments in terms of its tourism business, such as the construction of various cafes, bars, beach clubs, hotels and villas sought by tourists today. With the development of Canggu Village certainly has consequences that the community must be prepared to accept the impact of tourism that occurs both from environmental, socio-cultural and economic aspects. Collaboration between the local government, investors and the surrounding community is needed to minimize the impact of tourism that will occur because in essence tourism will provide a lot of income for regions that are aware of their potential towards the tourism sector (Abdillah \& Hamid, 2016; Amerta, 2017).

\section{Literature Review}

\section{Definition of Tourism}

According to Pitana \& Gayatri (2005), tourism is a whole of related elements (tourists, tourist destinations, travel, industry, etc.) which is a result of travel to tourist destinations as long as the trip is not permanent. It can be concluded that tourism is a voluntary and temporary travel activity to enjoy tourist objects and attractions. Tourism also aims at recreation, entertainment or refreshing.

\section{Benefits of Tourism}

Pendit (2002), states that tourism can provide a direct boost to the progress of the construction or improvement of ports (sea or air), roads, local transportation, hygiene or health programs, cultural facilities, and environmental sustainability 
projects, and so on, all of which can provide benefits and pleasure both for tourists in the environment of the region concerned, as well as for tourists from outside visitors. Tourism can also provide encouragement and contribution to the implementation of development projects of various sectors for countries that have developed or developed economically, where in turn the tourism industry is a reality in the midst of other industries.

\section{The role of tourism}

The natural and cultural potential of developing countries can be used as capital for tourism development in the country so that it can be developed as an economic activity. As a service industry, tourism plays an important role in policies regarding employment opportunities because of the increasingly urgent demand for employment opportunities in line with the increase in tourism in the future (Spillane, 1994; Pemayun \& Maheswari, 2017; Netra, 2015). On the demand side, the impact of the tourism industry has infiltrated various economic activities and spread rapidly through various related industries. The economic impact covers a broad spectrum of policies, involving business opportunities, employment opportunities, transportation, accommodation, infrastructure, regional development, taxation, trade, and the environment. The tourism industry, in particular, is said to be very effective in supporting small businesses and creating employment opportunities for young people as well as spreading employment opportunities, both regionally, nationally and internationally (Yoeti, 2008; Korry \& Suartini, 2019). According to Wahab (1996), said: "It is an important factor of economic development, as it motivates the development of several sectors on the national economy." Tourism is an important factor in the economic development of a country because it encourages the development of several sectors of the national economy.

\section{Materials and Methods}

The research population is the local community of Canggu Village, the method of determining the sample uses probability sampling with a distribution of 210 respondents. The method of data collection uses a Likert scale questionnaire. The analysis technique used is the path analysis technique. Ghozali (2013), defines path analysis (path analysis) is an extension of multiple linear regression analysis in estimating causality relationships between variables that have been predetermined based on theory. Path analysis is used to determine the pattern of relationships between three or more and cannot be used to confirm or reject hypotheses.

\section{Results and Discussions}

Table 2

Statistic descriptive

\begin{tabular}{llllll}
\hline & $\mathrm{N}$ & Minimum & Maximum & Mean & Std. Deviation \\
\hline $\mathrm{X}$ & 210 & 18.00 & 25.00 & 21.1714 & 2.48231 \\
Y1 & 210 & 21.00 & 30.00 & 25.2714 & 2.49931 \\
Y2 & 210 & 21.00 & 30.00 & 25.2429 & 2.52700 \\
Y3 & 210 & 14.00 & 20.00 & 16.8762 & 2.02707 \\
Valid N (listwise) & 210 & & & & \\
\hline
\end{tabular}

Primary Data, 2019

Descriptive statistics give an overview of each variable that shows the average value (mean), standard deviation, maximum value, and minimum value. The mean (average) value of variable $\mathrm{X}$ (Tourism Development) is 21.17 where the value approaches the maximum value, so it can be concluded that the Development of Tourism in the Canggu Village is at an optimal level. The maximum value of the planet's pillars is 25 while the minimum value is 18 . The standard deviation values indicate the average deviation of tourism development data of 2.482 from the expected value. The mean (average) value of the $\mathrm{Y} 1$ variable (Economy) is 25.27 where the value approaches the maximum value of 30, so it can be concluded that the Economic Aspects of Canggu are at an optimal level with a minimum value of 21.

Pratama, I. G. S., \& Mandaasari, I. A. C. S. (2020). The impact of tourism development on the economic, cultural and environmental aspects of local communities. International Research Journal of Management, IT and Social Sciences, 7(1), 31-36. https://doi.org/10.21744/irjmis.v7n1.819 
The standard deviation values indicate the average deviation of tourism development data of 2,499 from the expected value.

The mean (average) value of the Y2 (Culture) variable is 25.24 where the value approaches the maximum value of 30 , so it can be concluded that the Cultural Aspects of the Canggu community are still at optimal levels with a minimum value of 21. Standard deviation values show the average deviation of tourism development data of 2,527 from the expected value.

The mean (average) value of the Y3 (Environmental) variable is 16.87 where the value approaches the maximum value of 20, so it can be concluded that the Economic Aspects of the Canggu community are at optimal levels with a minimum value of 14 . The standard deviation values indicate the average deviation of tourism development data of 2,027 from the expected value. The path coefficient calculation is done by regression analysis through software (SPSS) 17.0 for Windows obtained from the results shown in the following table:

Table 3

Results of regression equation path analysis 1 development of tourism against the economy

\begin{tabular}{llll}
\hline \multirow{2}{*}{ Model } & \multirow{2}{*}{$R$ Square } & \multicolumn{2}{l}{ Standardized Coefficients } \\
\cline { 3 - 4 } Sig. & Beta & 0,000 \\
\hline Tourism Development $(\mathrm{X})$ & 0,910 & 0,961 & 0 \\
\hline
\end{tabular}

Primary Data, 2019

Based on Table 3 above, it is known that the significance value of the variable of tourism development is $0,000<0.05$, this shows that the variable of tourism development has a significant effect on economic variables. The value of $\mathrm{R}$ square is 0.910 , this means that the contribution of the variable tourism development (X) to the economy (Y) is $91 \%$, while the remaining $9 \%$ is influenced by other variables not included in the study.

The results of the analysis of tourism development affect the economic variables obtained by the value of Sig. $t$ of 0,000 with a beta coefficient of 0.961 . Sig value t $0,000 \leq 0.05$ indicates that $\mathrm{H} 0$ is rejected and $\mathrm{H} 1$ is accepted. This result means that the tourism development variable has a significant and positive effect on the economic variable.

These results mean that the increasing development of tourism in the Canggu area will also improve the economy of the local community. The economic improvement felt by the community can be seen from the creation and opening of employment opportunities, generating income for the local community, and increasing the standard of living of the local community of Canggu Village.

Table 4

Results of analysis of path regression equations 2, development of tourism against the culture

\begin{tabular}{|c|c|c|c|}
\hline \multirow{2}{*}{ Model } & \multirow{2}{*}{$R$ Square } & Standardized Coefficients & \multirow{2}{*}{ Sig. } \\
\hline & & Beta & \\
\hline Tourism Development (X) & 0,830 & 0,920 & 0,000 \\
\hline
\end{tabular}

Primary Data, 2019

Based on Table 4 above, it is known that the significance value of the variable of tourism development is $0,000<0.05$, this shows that the variable of tourism development has a significant effect on cultural variables. The value of $\mathrm{R}$ square is 0.830 , this means that the contribution of tourism development variable (X) to culture (Y) is $83 \%$, while the remaining $17 \%$ is influenced by other variables not included in the study.

The results of the analysis of tourism development affect the cultural variables obtained by the value of Sig. $t$ of 0,000 with a beta coefficient of 0.920 . Sig value $t 0,000 \leq 0.05$ indicates that $\mathrm{H} 0$ is rejected and $\mathrm{H} 1$ is accepted. These results mean that the variable of tourism development has a significant and positive effect on cultural variables.

These results have the meaning that the increasing development of tourism in the Canggu area will also enhance the cultural preservation of the community. The development of tourism is able to encourage the community to maintain and protect the assets of local cultural activities and be able to encourage people to accept and respect other cultures. 
Table 5

Results of analysis of path regression equations 3, development of tourism against the environment

\begin{tabular}{|c|c|c|c|}
\hline \multirow{2}{*}{ Model } & \multirow[b]{2}{*}{$R$ Square } & Standardized Coefficients & \multirow{2}{*}{ Sig. } \\
\hline & & Beta & \\
\hline Tourism Development (X) & 0,964 & 0,982 & 0,000 \\
\hline
\end{tabular}

Primary Data, 2019

Based on Table 5 above, it is known that the significance value of the variable of tourism development is $0,000<0.05$, this shows that the variable of tourism development has a significant effect on environmental variables. The value of $\mathrm{R}$ square is 0.964 , this means that the contribution of tourism development variable $(\mathrm{X})$ to the environment $(\mathrm{Y})$ is $96.4 \%$, while the remaining $3.6 \%$ is influenced by other variables not included in the study.

The results of the analysis of tourism development affect the environmental variables obtained by the value of Sig. $t$ of 0,000 with a beta coefficient of 0.964 . Sig value t $0,000 \leq 0.05$ indicates that $\mathrm{H} 0$ is rejected and $\mathrm{H} 1$ is accepted. This result means that the tourism development variable has a significant and positive effect on the environment variable.

These results have the meaning that the increasing development of tourism in the Canggu area will also increase environmental sustainability. In other words, the development of tourism shown by local people is able to improve environmental sustainability as well as planned and controlled infrastructure development.

\section{Conclusion}

Based on the results of the discussion through proof of the hypothesis of the examined problem, the conclusions that can be drawn from this study are:

a) The Impact of Tourism Development has a positive and significant effect on the economy of the local community of Canggu Village. It means that the development of tourism in Canggu Village will be accompanied by an increase in the economy of the local community.

b) 2) The Impact of Tourism Development has a positive and significant effect on the culture of the local community of Canggu Village. It means that the development of tourism stakeholders in Canggu Village will make the community more concerned about the preservation of Culture because the culture has its own charm and contributes to the development of Bali tourism.

c) 3) The Impact of Tourism Development has a positive and significant effect on the environment of the local community of Canggu Village. It means that the development of tourism can increase public awareness to maintain infrastructure and preserve the environment around Canggu Village.

\section{Suggestion}

Further researchers are advised to analyze the negative impacts of tourism development on the Economy, Culture and environment sectors. Future studies are suggested to examine the effect of tourism development on other variables such as social and political.

\section{Conflict of interest statement}

The authors declared that they have no competing interests.

Statement of authorship

The authors have a responsibility for the conception and design of the study. The authors have approved the final article.

\section{Acknowledgments}

The authors would like to thank the reviewer for their consideration of the further process of the present paper. Thanks to the editor of IRJMIS for the valuable support, time as well as advice.

Pratama, I. G. S., \& Mandaasari, I. A. C. S. (2020). The impact of tourism development on the economic, cultural and environmental aspects of local communities. International Research Journal of Management, IT and Social Sciences, 7(1), 31-36. https://doi.org/10.21744/irjmis.v7n1.819 
References

Abdillah, A. B. Y., \& Hamid, D. (2016). Dampak Pengembangan Pariwisata Teradap Kehidupan Masyarakat Lokal Di Kawasan Wisata (Studi Pada Masyarakat Sekitar Wisata Wendit, Kabupaten Malang). Jurnal Administrasi Bisnis, 30(1), 74-78.

Amerta, I. M. S. (2017). Community based tourism development. International Journal of Social Sciences and Humanities, 1(3), 97-107. https://doi.org/10.29332/ijssh.v1n3.60

Amerta, I. M. S., Sara, I. M., \& Bagiada, K. (2018). Sustainable tourism development. International Research Journal of Management, IT and Social Sciences, 5(2), 248-254.

Ghozali, I. (2006). Aplikasi analisis multivariate dengan program SPSS.

Korry, P. D. P., \& Suartini, N. W. (2019). Hedonism and culture toward impact of shopping behavior. International Journal of Social Sciences and Humanities, 3(1), 125-133. https://doi.org/10.29332/ijssh.v3n1.260

Netra, I. M. (2015). Meaning configuration of cultural practices in Bali as a model to strengthen identity of Balinese people. International Research Journal of Management, IT and Social Sciences, 2(7), 25-32.

Pemayun, A. G. P., \& Maheswari, A. I. A. (2017). Economic impacts of craftsman statue on community based tourism development. International Journal of Social Sciences and Humanities, 1(3), 59-73. https://doi.org/10.29332/ijssh.v1n3.56

Pendit, N. S. (2002). Ilmu Pariwisata Sebuah Pengantar Perdana-Cet. 8 (Edisi Terbaru) dengan PerbaikanPerbaikan. Penerbit Pradnya Paramita: Jakarta.

Pitana, I. G., \& Putu, G. Gayatri, 2015 Sosiologi Pariwisata. Yogyakarta: Andi Offset.

Putri, A. P., \& Abdillah, Y. (2019). Analisis perkembangan industri pariwisata dan perubahan nilai budaya pada kelurahan ubud kabupaten gianyar. Jurnal Administrasi Bisnis, 68(1), 9-18.

Spillane, J. J. (1994). Pariwisata Indonesia: siasat ekonomi dan rekayasa kebudayaan (Vol. 5). Kanisius.

Wahab, S. (1996). Tourism Management (Manejemen Kepariwisataan).

Yoety, O. A. (2008). Ekonomi pariwisata: introduksi, informasi, dan aplikasi. Penerbit Buku Kompas. 